
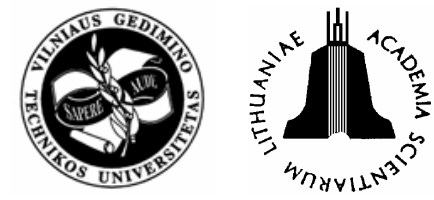

\title{
ANALYSIS OF THE EFFECTS OF MINERAL ADMIXTURES ON THE STRENGTH OF MORTARS: APPLICATION OF THE PREDICTIVE MODEL OF FERET
}

\author{
Abdelaziz Boudchicha ${ }^{1}$, Mustapha Cheikh Zouaoui ${ }^{1}$, Jean-Louis Gallias ${ }^{2}$, Bouzidi Mezghiche ${ }^{3}$ \\ ${ }^{1}$ Dept of Civil Engineering, University of Larbi Ben Mehidi, 04000 Oum Bouaki, Algeria \\ E-mail: aboudchicha@yahoo.fr, czmustapha@yahoo.fr \\ ${ }^{2}$ Laboratory for Mechanics and Materials in Civil Engineering, University of Cergy-Pontoise, \\ Site de Neuville, UFR Sciences et Techniques, 5 Mail Gay-Lussac, 95011 Neuville-Sur-Oise Cedex, \\ France.E-mail: jean-louis.gallias@iupgc.u-cergy.fr \\ ${ }^{3}$ Dept of Civil Engineering, University of Mohamed Khider, 07000 Biskra, Algeria \\ E-mail: bmezghiche@yahoo.fr
}

Received 21 Feb 2006; accepted 6 Feb 2007

\begin{abstract}
The introduction of fine and ultra-fine mineral admixtures in cementing materials generates a granular effect, a physico-chemical and micro-structural effect and, possibly, chemical effect. To analyse the specific share of each effect, we propose to use a methodology based on a volume substitution of cement by admixtures in mixes whose absolute volume of the solid phases and workability are preserved constant and then only the effects of the particles of admixtures in the cementing phase are taken into account. We expressed the compressive strength of mortars with admixtures according to a factor of compactness by applying to the mortars the principles of the predictive model of Feret. This factor makes possible to distinguish the modifications generated by the granular effect of the admixtures on the compactness of the cementing matrix independently of the physico-chemical and chemical effects. The specific chemical action of each admixture has been evaluated by analysing the variation of the coefficient of activity $K$ according to the rate of the cement substitution, by applying to the studied mortars the concept of the equivalent binder and by deducing the coefficient of activity from the predictive model of Feret.
\end{abstract}

Keywords: mortar, mineral admixtures, water requirement, compactness, mechanical strengths, granular effect, physico-chemical effect, chemical effect, predictive model of Feret.

\section{Introduction}

The recent studies which considered the influence of the mineral admixtures on the properties of cementing materials showed that those admixtures by their smoothness and a more or less significant reactivity with the cement, can generate in certain cases significant modifications in the rheological and mechanical properties. The mechanisms at the origin of these modifications appear particularly complex, but several studies in this field agree to distinguish 3 principal effects which are superimposed to influence the properties of the cementing material in the fresh or hardened state: a granular effect, a physico-chemical and micro-structural effect and a chemical effect.

The granular effect relates to all the modifications induced by the presence of the mineral admixtures in the granular structure of a cementing material in a fresh state. These modifications can result from the capacity of stacking of the fine or ultra-fine particles of the admixture with other solid components of the mixture and/or the intensity of frictions between particles. Several studies showed the existence of an optimisation of the granular structure properties by the incorporation of mineral admixtures of different natures and quantities. Kronlof [1] has demon- strated that the incorporation of 3 admixtures of quartz of different smoothness in a formulation of concrete leads to the reduction of the water requirement in relation to the proportioning and the smoothness of the material of substitution. Kwan [2] showed that the workability of a concrete increases with the percentage of silica fume for the constant water/binder ratio. In the same way, De Larard et al [3] demonstrated that the workability of a mortar varies according to the quantity of built-in silica fume. On the another hand, Bessa et al [4] showed that the granular effect of the mineral admixtures on the formulations of mortars could involve an increase or decrease of the water requirement with standardised workability, and depends initially on the smoothness and the quantity of the introduced admixture. Gallias et al [5] disclosed that the introduction of admixtures with great proportions into the cement pastes with a standardised workability generates a higher water requirement. Then, when the admixture particles modify lightly the frictions between the grains and fill the porosities of the granular structure (cement and aggregates) by releasing the water in these pores, the granular effect becomes favourable and leads to improving the workability of the fresh mix with a constant quantity of water, or to the reduction of water for a given workability and to improving the compactness of 
the mixture and the mechanical performances. But, when the particles of the admixture modify considerably the frictions between the grains in the cementing mixtures or do not fill porosities of the granular structure, the granular effect becomes unfavourable.

The physico-chemical and micro-structural effect relates to all the modifications generated by the multiple interactions between the mineral admixtures particles on the hydration process of cement, and on structuring the hydrated products. Lilkov [6] showed that the quantity of the hydrates formed during the first $24 \mathrm{~h}$ in a cementing paste is more significant in mixtures with admixtures of silica fume and fly-ashes that in mixtures without admixtures. Hanna [7] showed that the quantity of heat released during the first $24 \mathrm{~h}$ in a cementing paste is modified by the incorporation of various percentages of silica fume. Jiang and Van Damme [8] confirmed these results by studying the action of the siliceous and limestone admixtures on the process of hydration of the pure $\mathrm{C}_{3} \mathrm{~S}$. Feldman and Cheng-Yi [9] and Gutteridge and Dalziel [10] showed that the mineral admixtures play a role of preferential sites of nucleation during the cement reactions, allowing a better distribution of the hydrated products and thus lead to more effective structuring the cementing matrix. It thus results that the physicochemical and micro-structural effect of the mineral admixtures acts primarily on the evolution of the mechanical strengths at youth ages and on the physical and microstructural properties of the hardened cementing materials.

The chemical effect relates to the capacity of the admixtures characterised by pozzolanic and/or hydraulic properties, to react with water and the anhydrous or hydrated components of cement to form new mineral phases which can contribute to the evolution of the mechanical strengths as well as the hydrated products of cement. Appa Rao [11] showed that for a constant water/binder ratio equal to 0,5 , the incorporation of a silica fume in a mortar in the limit of $30 \%$ of the cement substitution by the admixture, leads to an increase in the compressive strengths independently of the age of mortar. Kwan [2] also showed that independently of the water/binder ratio, the incorporation of a silica fume in a mortar in the limit of $15 \%$ of the cement substitution by the admixture, leads to an increase in the compressive strengths in 28 days. Benzet and Benhassine [12] showed that the crystallised quartz finely crushed can react under certain conditions with the portlandite, but the quantification of the chemical activity separately of the physico-chemical and micro-structural effect is difficult and uncertain. In the same way, Lawrence [13] showed that the degree of hydration of mortars containing admixtures of quartz was more significant than that of the mortars without admixtures. Cyr et al [14], confirmed the chemical reactivity of the limestone admixtures by comparing the evolution of the mechanical strengths of mortars made with two flyashes and a limestone admixture. It results that the chemical effect, when it is favourable, is complementary to the physico-chemical and micro-structural effect.

A more general approach was advanced by Lawrence [15] who showed that the consideration of a coeffi- cient $\mathrm{K}$ which indicates the activity of the admixtures with standard values as in the French or European standardisation could not be used in the predictive models. Works of Lawrence have been confirmed by Kara Ali [16] who used a different experimental approach and considering a significant number of admixtures different by their mineral, chemical and morphological natures.

Indeed, the European standardisation EN 206-1 [17], defines a standard coefficient $\mathrm{K}$, taking into account the mineral admixtures in partial substitution of cement in the formulation of concretes by considering the concept of the equivalent binder. This coefficient $\mathrm{K}$ is only given for the fly-ashes and the silica fume with all the types of cement. Whereas the French standardisation P 18-305 for the ready-mixed concretes [18] makes possible to extend the concept of the coefficient $\mathrm{K}$ to the slag of blast furnace, limestone and siliceous admixtures, but only when they are substitutable with the cement CEM I of class 42.5 and higher.

In addition, the most recent experimental methodologies do not take into account the granular effect generated by the introduction of the mineral admixtures into cementing mixtures, whereas it can influence significantly the activity indices, and then the homogenisation of the experimental conditions always poses problems due to the modification of the rheological properties of the cementing materials in the presence of admixtures. Thus it results that these standardisations do not propose a rigorous and single methodological procedure to define the coefficient of activity $\mathrm{K}$ of a binder including cement and a standardised mineral admixture.

On the another hand, it is important to note that in the majority of the published studies and in accordance with normative texts, the mineral admixtures were introduced in the mixture in a mass substitution of cement. In this case the absolute volume of the binder (cement + admixture) grows proportionally at the rates of the cement substitution and the modifications in the cementing matrix are more significant as this rate increases and the difference between the specific gravity of cement and that of the admixture is significant. These modifications can influence the properties of the hardened mixtures and involve uncertainty in the evaluation of the different actions of the mineral admixtures on the cementing materials properties. Thus in case of a mass substitution of cement by the admixture, the absolute volume of the mortar increases and the volume ratio water/solid decreases. But in case of the volume substitution of cement, the absolute volume of the mortar and the volume ratio (water/solid) remains unchanged. In this case the compactness of the granular structure and the porosity of the cementing matrix of the mortar with admixtures remain comparable with that of the mortar without admixture and only the effects of the admixture particles are taken into account in the cementing phase.

In order to evaluate all the contributions of admixtures to the mortars, we propose to use a specific methodology which is based on the progressive volume substitution of cement by mineral admixtures in mortars whose absolute volume of the whole solid constituent and 
the workability of the mixtures are preserved constant [4, $5,16,19,20]$.

\section{Methodology}

In order to evaluate all the contributions of admixtures to mortars, we measured all the parameters which characterise the rheological and mechanical properties of the mortars and we were particularly interested in the following properties:

- the water requirement, compactness and the volume of the included air for mortars having constant workability;

- the mechanical strengths;

- the effects of the mineral admixtures on the compressive strength.

To reach this purpose, we prepared a mortar of reference without admixtures whose composition is inspired by that of the normal mortar defined by NF EN 196-1 standardisation [17], with a quantity of water adjusted to obtain reference workability.

The procedures followed for preparing mortars, testcubes, vibrating, storage, and measurement of the compressive strengths were accomplished in conformity with NF EN 196-1 standardisation [17].

The preparation of the mortar was carried out by a mixer of a capacity of $5000 \mathrm{~cm}^{3}$, composed of a container and a beater of stainless steel, able to function at a slow speed of 140 turns per min and a fast speed of 285 turns per min.

Water and cement with or without admixtures were introduced into the container in the stop position. The mixer is started at slow speed during $60 \mathrm{sec}$, then at fast speed during $30 \mathrm{sec}$; the sand is introduced at the first 30 sec. After stopping the mixer during $90 \mathrm{sec}$, it is restarted at high speed for $60 \mathrm{sec}$.

The reference workability was evaluated by measuring the spread of the fresh mortars on a vibrating table placed in two layers and compacted by a metal stem, in a cone of a lower diameter of $100 \mathrm{~mm}$, a higher diameter of $70 \mathrm{~mm}$ and a height of $60 \mathrm{~mm}$. After removal of the cone, the table undergoes 30 jolts in $30 \mathrm{sec}$ and the value of the considered spreading, constitutes the average of the measurement of spreading the mixture in two perpendicular directions.

For each mortar having acquired the reference workability, we prepared $40 \mathrm{~mm} \times 40 \mathrm{~mm} \times 40 \mathrm{~mm}$ testcubes. The mortar was cast in metallic moulds in two layers, and undergoes 60 jolts in $60 \mathrm{sec}$ per layer, on a table of shocks. The moulds were kept in a wet room for $24 \mathrm{~h}$ at $20{ }^{\circ} \mathrm{C}$ and more than $95 \%$ of relative humidity. The test cubes were then demoulded and preserved immersed in water at $20 \pm 2{ }^{\circ} \mathrm{C}$, until required for testing.

The characterisation of the compressive strengths of mortars was carried out in 7 and 28 days, using a hydraulic testing machine. The value of the considered compressive strength constitutes the average of the results from 3 specimens.

The experimental procedure required the preparation of 108 formulations of mortars.
For this study, we indicated by:

$w$ : the volume of water used to obtain a mortar with the reference workability.

$b$ : the absolute volume of binder in the mortar. $b=c+a$

$c$ : the absolute volume of cement in the mortar.

$a$ : the absolute volume of the mineral admixture in the mortar.

\subsection{Evaluation of the water requirement, compactness and the volume of the occluded air for mortars having constant workability}

The water requirement is expressed by the variation of the volume ratio, quantity of water by the quantity of binder (w/b) according to the rate of the cement substitution by the mineral admixtures (in \%) for mortars with a constant workability.

The rate of the cement substitution by the mineral admixtures varies between 0 and $50 \%$. The quantity of water was adjusted each time for all the mortars made to acquire the workability of the mortar of reference.

The granular structure compactness for the fresh mortars was calculated on the basis of their apparent densities by taking into account the specific gravity of the solid components and their proportions in the mixture.

Then the compactness of the fresh mixtures was calculated by the following relation:

$$
\text { Compactness }=\left(\frac{C}{\rho_{c}}+\frac{A}{\rho_{A}}+\frac{S}{\rho_{s}}\right) \cdot\left(\frac{M V A}{C+A+S+W}\right) \text {, }
$$

where $M V A$ indicates the apparent density of the fresh mortar, measured for each formulation by manually filling a container with a known volume just after mixing, in $\left(\mathrm{kg} / \mathrm{m}^{3}\right) ; C, A, S$, and $W$ indicate respectively the proportioning of cement, admixture, sand and water in the fresh mixture, in $\left(\mathrm{kg} / \mathrm{m}^{3}\right) ; \rho_{C}, \rho_{A}$ and $\rho_{S}$ indicate respectively the specific gravity of cement, admixture and sand.

The masses and the volumes of the various components in the fresh mixture were calculated by the following relations:

$$
\begin{aligned}
& C=M V A \frac{M_{C}}{M_{C}+M_{S}+M_{A}+M_{W}}, \quad c=\frac{C}{\rho_{c}} \cdot 10^{3}, \\
& S=M V A \frac{M_{S}}{M_{C}+M_{S}+M_{A}+M_{W}}, \quad s=\frac{S}{\rho_{s}} \cdot 10^{3}, \\
& A=M V A \frac{M_{A}}{M_{C}+M_{S}+M_{A}+M_{W}}, \quad a=\frac{A}{\rho_{A}} \cdot 10^{3} \text {, } \\
& W=M V A \frac{M_{W}}{M_{C}+M_{S}+M_{A}+M_{W}}, \quad w=\frac{W}{\rho_{w}} \cdot 10^{3},
\end{aligned}
$$

where $c, s, a$ and $w$ indicate respectively the absolute volumes in $\left(\mathrm{m}^{3}\right)$ per $\mathrm{m}^{3}$ of mixture, of cement, sand, admixture and water; $M_{C}, M_{S}, M_{A}$ and $M_{W}$ indicate respectively the masses of these components used for preparing mixing, in $(\mathrm{kg}) ; \rho_{w}$ indicates the specific gravity of water, considered equal to $1000 \mathrm{~kg} / \mathrm{m}^{3}$.

The volume of the occluded air $(v)$ was calculated on the basis of the granular structure compactness and the 
water quantity in the cementing mixture, by supposing that the proportions of the solid and liquid components of the mixture are those used during the mixing.

\subsection{Evaluation of the mechanical strength}

The results are expressed by the relative strength $\left(f_{c D} / f_{c r D}\right)$, which is expressed by the ratio of the compressive strength at the D-day of the mortar with admixture, by the compressive strength of the mortar of reference at the same day, according to the rate of the cement substitution by the mineral admixture in the mortar (in \%):

$f_{c D}$ : compressive strength at the D-day of the mortar with mineral admixtures;

$f_{c r D}$ : compressive strength at the D-day of the mortar of reference without admixtures.

\subsection{Evaluation of the effects of mineral admixtures on the compressive strength}

When a fine or ultra-fine mineral admixture is introduced in a cementing mixture, it generates significant modifications in the properties of the cementing materials by a granular effect or/and a physico-chemical and microstructural effect or/and a chemical effect.

To take into account the specific share of these various effects, we initially highlighted the granular effect in a purely physical matter of the two other effects related to the hydration of cement. This distinction can be done by applying to the studied mortars the principles of the predictive model of Feret [21] which expresses the compressive strength of a concrete to a given age by the following relation:

$$
f_{c}=G_{f} f_{m c}\left(\frac{c}{c+w+v}\right)^{2}
$$

where $G_{f}$ indicates a coefficient which depends on the nature of the aggregates; $f_{m c}$ indicates the compressive strength of the normal mortar at the same age in (MPa); $c, w$ and $v$ indicate respectively the volumes of cement, water and occluded air in $\left(1 / \mathrm{m}^{3}\right)$.

The predictive model of Feret expresses the compressive strength of a concrete on the basis of 3 factors supposed independent:

- A factor $G_{f}$ indicating the influence of the aggregates on the compressive strength;

- A factor indicating the contribution of the nature and the characteristics of the cement on the evolution of the strength, expressed directly by the compressive strength of the normal mortar $f_{m c}$, prepared with standardised sand at the same age as the concrete;

- A factor indicating the contribution of the initial compactness of the cementing matrix to the compressive strength expressed by the report $\left[(c /(c+w+v)]^{2}\right.$, which will be indicated in this study, by the factor of compactness and depend on the parameters of concrete formulation.

The consideration of the compressive strengths variation of the mortars with admixtures according to the compactness factor will make possible to highlight the modifications generated by the granular effect of the admixtures on the cementing matrix compactness inde- pendently of other effects. The physical effect of the admixture can be evaluated in Figs 6 and 7 by analyzing the shift of the relative strength curve in report to the curve of reference of the mortar without admixtures in parallel to the $\mathrm{x}$-axis (factor of axis compactness), and the physicochemical and chemical effects can be deduced by analysing the shift of the relative strength curve in report to the curve of reference of the mortar without admixtures in parallel to the y-axis (relative strength axis).

To distinguish the specific chemical activity for each admixture, we can base on the concept of the equivalent binder $B$ which is defined in NF P18 305 standardisation [18] by the following relation:

$$
B=C+K A,
$$

where $K$ indicates the coefficient of activity of the admixture and $B$ the mass of binder in the mixture.

By applying this concept to the studied mortars, and because $G_{F}$ and $f_{m c}$ are invariable for all the mixtures (the same cement and sand), the relative compressive strength can be deduced by the predictive model of Feret:

$$
\frac{f_{c}}{f_{c r}}=\frac{(b /(b+w+v))^{2}}{\left(c_{r} /\left(c_{r}+w_{r}+v_{r}\right)\right)^{2}},
$$

where $c_{r}, w_{r}$ and $v_{r}$ indicate respectively the volumes of cement, water and occluded air in the mortar without admixtures in $\left(l / \mathrm{m}^{3}\right) ; b, w$ and $v$ indicate respectively the volumes of binder, water and occluded air in the mortar with admixtures in $\left(\mathrm{l} / \mathrm{m}^{3}\right)$.

As the volume of the equivalent binder can be given by

$$
b=c+K a,
$$

and by considering Eq 6 in Eq 5, we can deduce directly the coefficient of activity $K$ :

$$
K=\frac{c_{r}(w+v) \sqrt{f_{c} / f_{c r}}}{a\left[c_{r}\left(1-\sqrt{f_{c} / f_{c r}}\right)+\left(w_{r}+v_{r}\right)\right]}-\left(\frac{c}{a}\right) .
$$

The analysis of the variation of the coefficient of activity $K$ according to the rate of the cement substitution can inform us on the specific chemical activity for each admixture studied.

\section{Materials}

\subsection{Cement}

The cement used for manufacturing the ordinary concretes in Algeria.

- Designation: Cement CPJ, CEM II/A 42.5.

- Production: Cement factory of Ain Touta, Dept of Batna, Algeria.

- Specific gravity: $3100 \mathrm{~kg} / \mathrm{m}^{3}$.

- Specific surface (Blaine): $3200 \mathrm{~cm}^{2} / \mathrm{g}$.

Chemical and mineralogical compositions of clinker are presented in Tables 1 and 2, respectively.

Table 1. Chemical composition of the clinker

\begin{tabular}{l|lllllll}
\hline Components & $\mathrm{CaO}$ & $\mathrm{SiO}_{2}$ & $\mathrm{Al}_{2} \mathrm{O}_{3}$ & $\mathrm{Fe}_{2} \mathrm{O}_{3}$ & $\mathrm{MgO}$ & $\mathrm{SO}_{3}$ & $\mathrm{LOI}$ \\
\hline$\%$ & 64,36 & 22,0 & 5,02 & 2,94 & 2,07 & 1,94 & 0,64 \\
\hline
\end{tabular}


Table 2. Mineralogical composition of the clinker (Bogue)

\begin{tabular}{l|llll}
\hline Minerals & $C_{3} S$ & $C_{2} S$ & $C_{3} A$ & $C_{4} A F$ \\
\hline$\%$ & 51,28 & 24,68 & 8,33 & 8,94 \\
\hline
\end{tabular}

\subsection{Sand}

A river sand is used for manufacturing ordinary concretes in Algeria.

- Designation: River sand.

- Origin: Lioua Dept of Biskra, Algeria.

- Specific gravity: $2600 \mathrm{~kg} / \mathrm{m}^{3}$.

- Fineness modulus: 2,5.

- Equivalent of sand: $78 \%$.

\subsection{Admixtures}

The mineral admixtures used are different by their mineralogical nature, chemical composition and granularity. For this study we considered 4 fine admixtures (3 kinds of limestone different by their smoothness, one quartz) and one ultra-fine admixture (silica fume) currently used for new concretes in developed countries (Table 3).

Table 3. Physical characteristics of admixtures

\begin{tabular}{l|ccc}
\hline Admixture & Designation & $\begin{array}{c}\text { Specific } \\
\text { gravity } \\
\left(\mathrm{kg} / \mathrm{m}^{3}\right)\end{array}$ & $\begin{array}{c}\text { Specific surface } \\
\text { Blaine } \\
\left(\mathrm{cm}^{2} / \mathrm{g}\right)\end{array}$ \\
\hline Limestone 1 & $\mathrm{Ca} 1$ & 2700 & 18500 \\
Limestone 2 & $\mathrm{Ca} 2$ & 2700 & 10500 \\
Limestone 3 & $\mathrm{Ca} 3$ & 2700 & 8000 \\
Quartz & $\mathrm{QZ}$ & 2650 & 11200 \\
Silica fume & $\mathrm{SF}$ & 2240 & $15(*)$ \\
\hline
\end{tabular}

$(*)$ : The smoothness of the silica fume was provided by the BET test in $\mathrm{m}^{2} / \mathrm{g}$.

\section{Tests and results}

\subsection{Making mortar}

The mortar of reference is made on the basis of the composition of the normal mortar defined by NF EN 196.1 standard [17], by using:

- $450 \mathrm{~g}$ of cement, corresponding to a volume of $145,16 \mathrm{~cm}^{3}$ in the mixture and to the volume of the binder with or without admixtures;

- $1350 \mathrm{~g}$ of ordinary sand (0-5), corresponding to a volume of $519,23 \mathrm{~cm}^{3}$ in the mixture and which is maintained constant in all the mixtures with or without admixtures;

- A quantity of water which was adjusted until obtaining the reference workability. The reference workability was selected equal to a spreading of $111 \mathrm{~mm}$ on the vibrating table, which required a quantity of water equal to $205 \mathrm{ml}\left(\mathrm{cm}^{3}\right)$ in making the mortar of reference.

The results obtained for this mortar:

- Workability by spreading on the vibrating table: $M=111 \mathrm{~mm}$.
- Compressive strength in 7 days:

$$
f c_{7}=36,19 \mathrm{MPa} \text {. }
$$

- Compressive strength in 28 days:

$$
f c_{28}=43,6 \mathrm{MPa} \text {. }
$$

To find a reference function to the mortars with admixtures, we carried out a progressive volume substitution of cement by sand in the mortar of reference until rates of $50 \%$. We noted the effect of this substitution on the water requirement, compactness, volume of the occluded air and the mechanical strength of the mortar without admixtures (NA), as well as in the study on the mortars with admixtures.

\subsection{Effect of cement substitution by mineral admixtures on the water requirement, compactness and the volume of the occluded air in mortars}

The substitution of the cement by admixtures volume, by volume with preserving an absolute volume of the solid components constant involves a variation of workability. To give to the mortar with admixtures the reference workability, the quantity of water must be adjusted and then involves a variation of the water requirement previously defined.

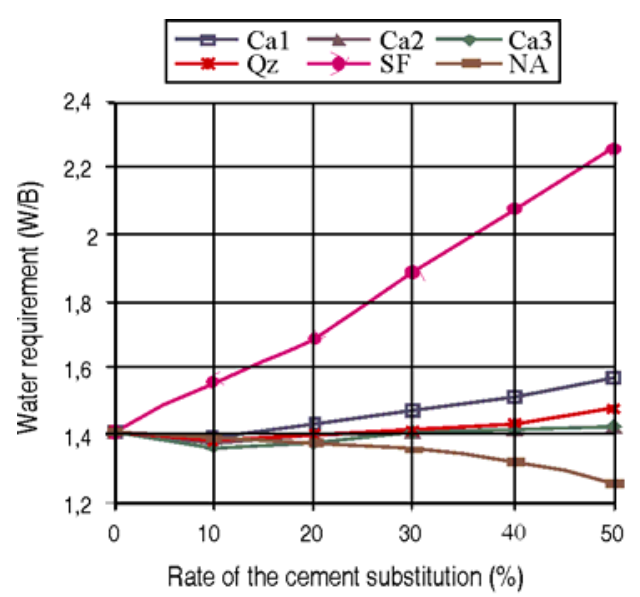

Fig 1. Effect of the cement substitution by mineral admixtures on the water requirement of mortars

The analysis of Fig 1 shows that the variation of the water requirement for the mortars with admixtures varies appreciably with the mineralogical nature and the granular characteristics (smoothness) of the built-in admixture. For the studied fine mineral admixtures (Ca1, Ca2, Ca3 and $\mathrm{Qz}$ ), the water requirement for the mortars with admixtures is more or less close to that of the mortar of reference. The water requirement for the 3 kinds of limestone admixtures (Ca1, Ca2 and $\mathrm{Ca} 3$ ) is more important as the smoothness is large and remains weaker than that of the mortar of reference for rates of substitution lower than $18 \%$.

It is also noticed that the mortar with silica fume presents the strongest water requirements in agreement with its large smoothness. The variation of the water requirement for the mortar without admixtures is downward. 
Then these results differ from those of Kwan [2] and De Larard et al [3], but join those of Bessa et al [4] and Gallias et al [5].

For weak rates of the cement substitution, the water requirement of the mortars with admixtures is directly related to the phenomena of granular stacking, thus depends on the compactness of fresh mixtures.

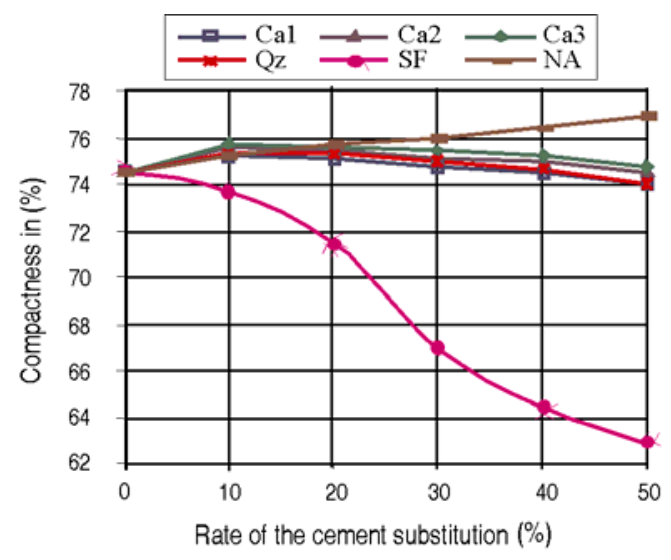

Fig 2. Effect of the cement substitution by mineral admixtures on the compactness of mortars

The analysis of Fig 2 shows that the compactness of the granular structure of the mortars with admixtures is related to the water requirement and follows an opposite variation. This is in spite of the presence of sand which tends to attenuate the relative extent of the variations of the density of granular stacking in the mixture. The observed optimisation of the water requirement for weak rates of the cement substitution can be explained by the weak compactness of the mortars.

A very good correspondence between the water requirement and the compactness of the mortars with admixtures is related to the fact that the tightening the granular structure of the mortars at the time of the mixing remains equivalent, independently of the nature and the characteristics of the admixtures because of the maintenance constant of the workability in the fresh mixtures. This can be confirmed by the calculation of the volume of the occluded air in the mortars.

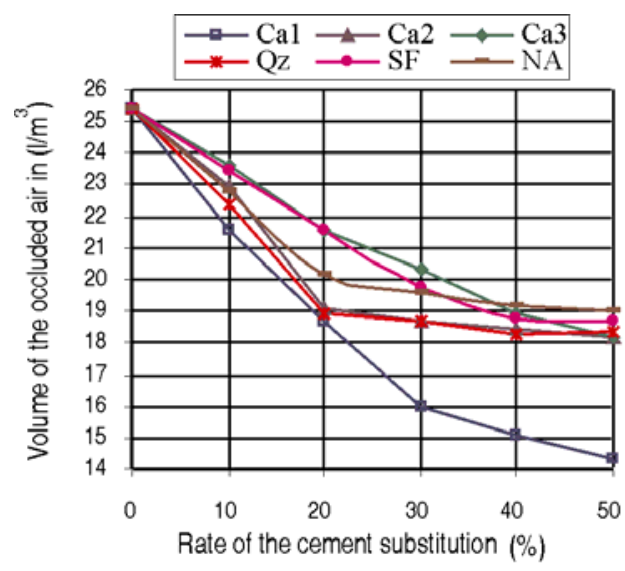

Fig 3. Effect of the cement substitution by mineral admixtures on the volume of the occluded air in mortars
The analysis of Fig 3 shows that the volume of the occluded air in the mortars varies between 14 and $26 \mathrm{l} / \mathrm{m}^{3}$ $(1,4$ and $2,6 \%)$, ie in a much reduced field.

\subsection{Effect of the cement substitution by mineral admixtures on the mechanical strength of mortars}

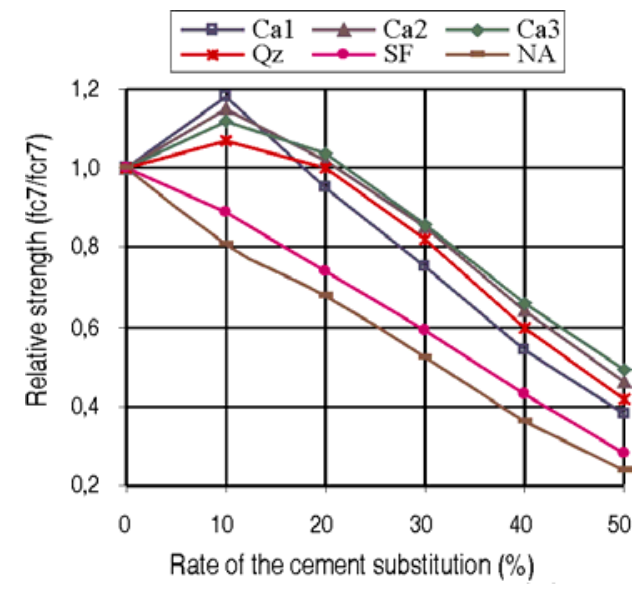

Fig 4. Effect of the cement substitution by the admixtures on the compressive strength of mortars in 7 days

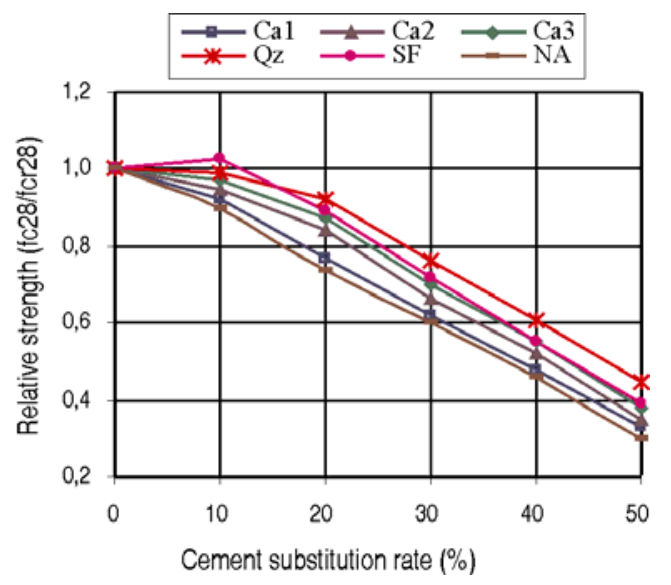

Fig 5. Effect of the cement substitution by mineral admixtures on the compressive strength of mortars in 28 days

The analysis of Figs 4 and 5 shows that for the studied fine mineral admixtures (Ca1, Ca2, Ca3 and Qz), the variation of the relative strength in 7 days grows for the weak rates of substitution and reached a maximum in the vicinity of $10 \%$ of the cement substitution, then starts to decrease. For the mortar with silica fume, the relative strengths in 7 days decrease directly without any improvement. The strength improvement in 7 days for the fine mineral admixtures which reaches rates of 18, 15, 12 and $7 \%$ for the mortars with $\mathrm{Ca} 1, \mathrm{Ca} 2, \mathrm{Ca} 3$ and $\mathrm{Qz}$ respectively did not reproduce for the strengths in 28 days and all of them are decreasing. For the mortar with a silica fume, the relative strength presents a light improvement of $3 \%$ in the vicinity of $10 \%$ of the rate of the cement substitution.

We can thus deduce that the action of fine mineral admixtures in cement is limited primarily to an acceleration of the hydration process at the young ages. This ac- 
celeration is more or less equivalent to all fine mineral admixtures. The opposite action of the silica fume is probably due to the relatively late pozzolanic reactions with the cement and with the introduction into the mixture increasing strongly the water requirement to the mortar and attenuating the chemical activity of particles.

These results confirm those of Lilkov et al [6], Jiang and Van damme [8], Gutteridge and Dalziel [10], Lawrence et al [13] on the limestone and the siliceous admixtures.

\subsection{Different effects of the mineral admixtures on the compressive strength}

The analysis of the relative compressive strength variation according to the rate of the cement substitution does not indicate the specific share of the effects generated by the presence of admixtures in the mortar (granular effect, physico-chemical and microstructural effect, and chemical effect). To distinguish these effects, we have traced the variation of the relative compressive strengths in 7 and 28 days according to the factor of compactness by Feret $\left[(c /(c+w+v)]^{2}\right.$, previously defined.

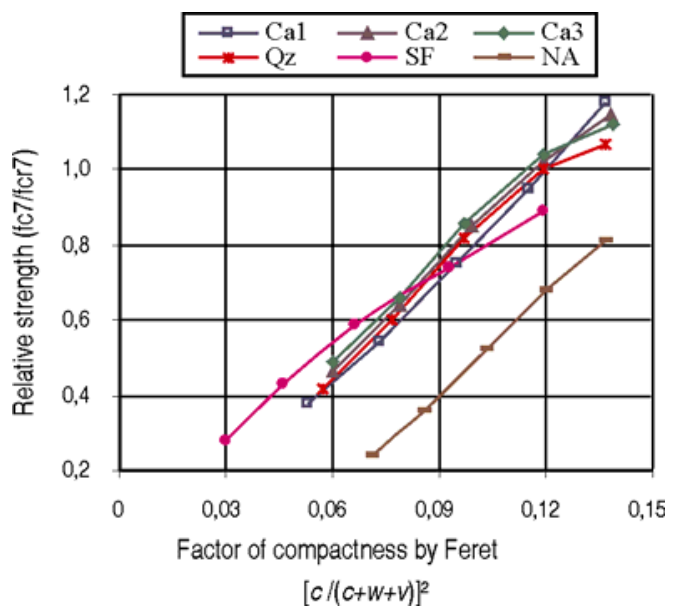

Fig 6. Evaluation of the relative compressive strength in 7 days according to the compactness factor $\left[(c /(c+w+v)]^{2}\right.$

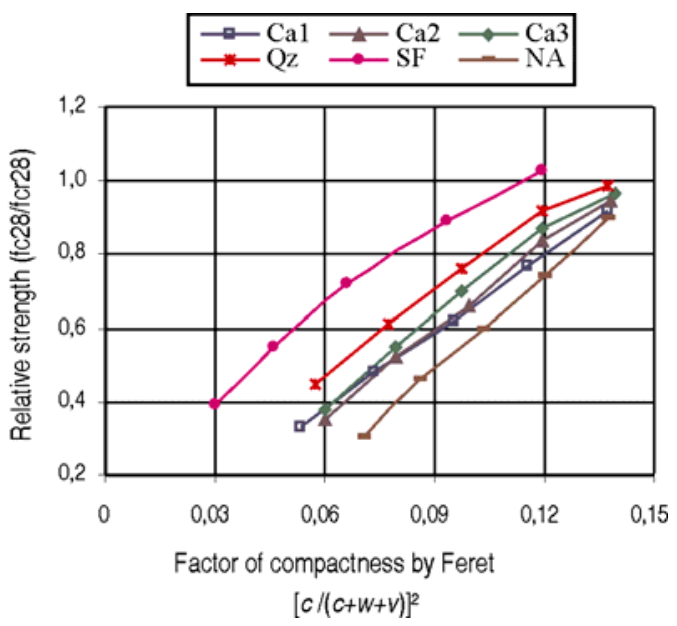

Fig 7. Evaluation of the relative compressive strength in 28 days according to the factor of compactness $\left[(c /(c+w+v)]^{2}\right.$
The analysis of Figs 6 and 7 shows that all the values of the relative strength of the mortars with admixtures in 7 and 28 days place left the reference curve of the mortar without admixtures, which implies that the incorporation of mineral admixtures in the mortars generate a more or less unfavourable granular effect in physical matter together with a more or less strong physico-chemical and possibly chemical activity.

In 7 days the variation of the relative strength compared to the curve of reference is significant. At weak rates of the cement substitution, the physico-chemical and chemical effect of calcites and quartz exceeds their physical effect and at strong rates of substitution, the silica fume becomes chemically more effective.

In 28 days, the silica fume characterised by a pozzolanic activity and a very high smoothness, presents the most significant chemical effect for all rates of the cement substitution, but in this case the compactness of the granular mixture is so low that strengths border those of the reference curve of the mortar without admixtures. The physico-chemical and chemical effects of calcites and quartz are in this case much attenuated.

This analysis confirms the results achieved by Feldman and Cheng-Gi [9], Gutteridge and Dalziel [10], Housson et al [22], Xi et al [23].

We can also note that the granular effect rather unfavourable stays often quantitatively comparable to the benefit obtained by the physico-chemical and chemical effects, which explains the maintenance of strength close to those of the reference curve of the mortar without admixtures, except for the silica fume which develops a significant physico-chemical and chemical activities probably due to the late pozzolanic reactions which compensate mainly the significant reduction in compactness and quantity of cement.

To distinguish the specific chemical activity in each admixture, we traced the variation of the coefficient of activity $K$, previously defined according to the rate of the cement substitution by the admixture.

The analysis of Figs 8 and 9 makes possible to note that the coefficients of activity of various mineral admixtures are very different and depend on their mineralogical and chemical nature, the rate of the cement substitution and the age of the mortar with admixtures.

Indeed, the coefficients of activity of the silica fume increase with time, whereas they decrease for all other studied admixtures. These coefficients of activity present maximum values at $10 \%$ of the rate of the cement substitution by reaching 2,2 for the limestone admixtures in 7 days and 2,3 for the silica fume in 28 days, and minimal values at $50 \%$ of the rate of the cement substitution while tending towards a zero value. In 7 days and at weak rate of the cement substitution, the limestone admixtures present the most significant coefficients of activity and are stronger when their smoothness is large. At more significant rates of the cement substitution, the silica fume becomes more active chemically and the quartz presents intermediate coefficients of activity between the calcites and the silica fume. 


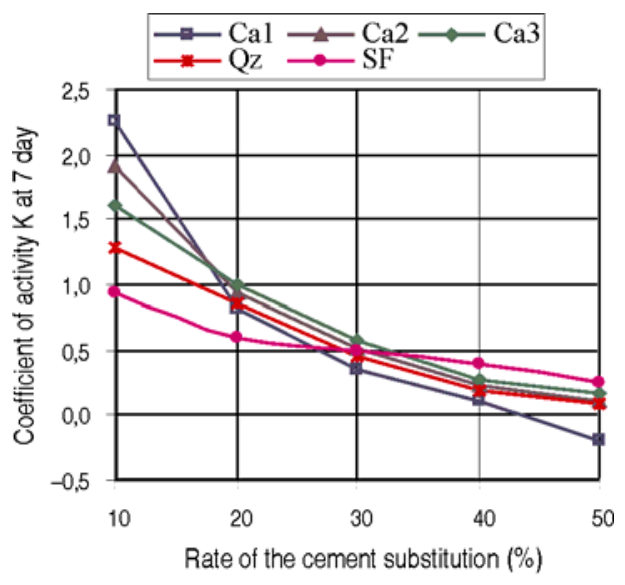

Fig 8. Evaluation of the coefficient of activity in 7 days, calculated on the basis of the predictive model of Feret according to the cement substitution rate

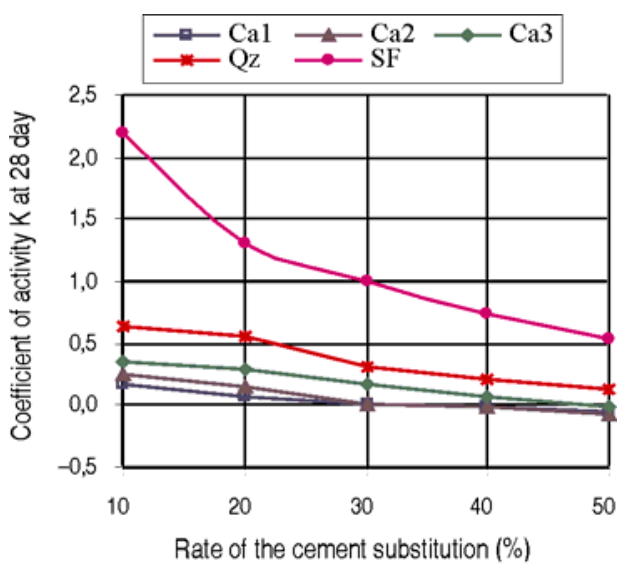

Fig 9. Evaluation of the coefficient of activity in 28 days, calculated on the basis of the predictive model of Feret according to the cement substitution rate

In 28 days, the silica fume presents more significant coefficients of activity than those of the limestone admixtures which are weaker as the smoothness is large. The quartz presents intermediate coefficients of activity between the silica fume and the calcites.

This analysis joined the results obtained by Kwan [2], Appa Rao et al [11], Benzet et al [12], Cyr et al [14], and Lawrence [15]. In addition, these results confirm the analysis carried out for the variation of the relative strengths according to the factor of compactness by Feret $\left[(c /(c+w+v)]^{2}\right.$, where we concluded that the silica fume presented a significant pozzolanic activity in 28 days and that it is a smoothness generated favourable physicochemical effects in 7 days and at strong rates of the cement substitution, whereas the limestone admixtures presented a favourable physico-chemical effect in 7 days which was attenuated considerably in 28 days.

It follows that the coefficients of activity of different admixtures are very sensitive to the parameters of formulation of the mortars (nature, proportions and time) and consequently this analysis differ from the concept of the equivalent binder recommended by the European standards $[17,18]$, which are based on a coefficient of the activity of standard values.

\section{Conclusions}

The approach applied enabled us to distinctly quantify the physical, physico-chemical and possibly chemical actions of different admixtures of mortars. It consists of a progressive volume substitution of cement by mineral admixtures in mortars the workability of which and the absolute volume of the whole solid constituent phases remained constant.

The achieved results showed that:

- The water requirement of mortars varies appreciably with the mineralogical nature and the granular characteristics of the built-in mineral admixture, and for the weak rates of the cement substitution, it is directly related to the phenomena of granular stacking, thus to the compactness of the fresh mixtures.

Then, for the mortars with the fine admixtures, it is more or less close to that of the mortar of reference and it is more important as the smoothness is large but remains weaker for rates of substitution lower than $18 \%$. The mortar with silica fume presents the strongest water requirements in agreement with its large smoothness.

- The action of the fine mineral admixtures on cement is limited primarily to an acceleration of the process of hydration at young ages. The opposite action of the silica fume is probably due to the relatively late pozzolanic reactions with the cement.

Then, the relative strength at 07 days grows with weak rates of substitution and reaches rates of 18, 15, 12 and $7 \%$ for the mortars with $\mathrm{Ca} 1, \mathrm{Ca} 2, \mathrm{Ca} 3$ and $\mathrm{Qz}$ respectively in the vicinity of $10 \%$ of the rate of the cement substitution. Then it starts to decrease, except for the mortar with silica fume which decreases directly without any improvement. This improvement did not reproduce the strength in 28 days.

- The distinction of the granular effect in the physical matter compared to the other two effects in relation to the process of hydration of cement have been evaluated on the basis of the predictive model of Feret, by expressing the relative strengths of the mortars with admixtures according to the factor of compactness by Feret.

Then in 7 days and, at weak rates of the cement substitution, the physico-chemical and chemical effect of calcites and quartz exceeds their physical effect and at strong rates of substitution, the silica fume becomes more chemically effective.

In 28 days the silica fume presents the most significant chemical effect for all rates of the cement substitution, but in this case the compactness of the granular mixture is low. The physico-chemical and chemical effects of calcites and quartz are in this case much attenuated.

- The specific chemical action of each admixture have been evaluated by analysing the variation of the coefficient of activity $K$ according to the rate of the cement substitution, by applying to the studied mortars the concept of the equivalent binder and by deducing the coefficient of activity $K$ from the predictive model of Feret.

In this case the coefficients of activity for the studied admixtures are very sensitive to the parameters of formulation of mortars, and consequently differ from the con- 
cept of the equivalent binder recommended by the readymixed concretes standardisation which is based on a coefficient of activity with standard values. Indeed, the coefficients of activity of the silica fume increase with time, whereas they decrease for all other studied admixtures. These coefficients of activity present maximum values at $10 \%$ of the rate of the cement substitution by reaching 2,2 for the limestone in 7 days and 2,3 for the silica fume at 28 days, and minimal values at $50 \%$ of the cement substitution while tending towards a zero value. In 7 days and at a weak rate of the cement substitution, the limestone admixtures present the most significant coefficients of activity and are stronger as their smoothness is large. At more significant rates of the cement substitution, the silica fume becomes more active chemically and the quartz presents intermediate coefficients of activity. In 28 days the silica fume presents more significant coefficients of activity than those of the limestone admixtures which are weaker as the smoothness is large. The quartz presents intermediate coefficients of activity.

Consequently, this approach can be used by considering the incorporation of superplasticisers to maintain a constant quantity of water in the mixture and generalised for various types of cements and a more significant number of fine and ultra-fine admixtures, to give possibilities to define criteria of performance for the admixtures and to make possible the control of the choice and the conditions of their incorporations in the formulation of concretes.

\section{References}

1. KRONLOF, A. Effect of very fine aggregate on concrete strength. Materials and Structures, 1994, 27(1), p. 15-25.

2. KWAN, A. K. H. Use of condensed silica fume for making high-strength, self-consolidating concrete. Canadian Journal of Civil Engineering, 2000, 27(4), p. 620-627.

3. DE LARARD, F.; MOREAU, A.; BUIL, M. and PAILLERE, A. M. Improvement of mortars and concretes really attributable to condensed silica fume. In Proc of $2^{\text {nd }}$ International Conference on Fly Ash, Silica Fume, Slag and Natural Pozzolans. Madrid, 1986, p. 959-971.

4. BESSA, A. and GALLIAS, J. L. Evaluation de la contribution des additions minérales à l'activité liante du ciment dans les mortiers. $21^{\text {ème }}$ rencontres universitaires de Génie Civil, 2003 (in French).

5. GALLIAS, J. L.; KARA, ALI R. and BIGAS, J. P. The effect of fine mineral admixtures on water requirement of the cement pastes. Cement and Concrete Research, 2000, 30(10), p. 1543-1549.

6. LILKOV, V.; DIMITROVA, E. and PETROV, O. Hydration process of cement containing fly ash and silica fume: the first 24 hours. Cement and Concrete Research, 1997, 27(4), p. 577-588.

7. HANNA, B. Contribution à l'étude de la structuration des mortiers de ciment Portland contenant des particules ultra-fines. Thèse de doctorat, INSA de Toulouse, France, 1987 (in French).

8. JIANG, S.; Van DAMME, H. Influence des fillers de nature différente sur l'hydratation de la texture des pâtes de $C_{3} S$. Rapport de CRMD-ATILH, Université d'Orléans, France, 1996 (in French).

9. CHENG-Yi, M. and FELDMAN, R. F. Hydration reactions in portland cement-silica fume. Cement and Concrete Research, 1985, 15(4), p. 585-592.

10. GUTTERIDGE, W. A. and DALZIEL, J. A. Filler cement: the effect of the secondary component on the hydration of portland cement. Cement and Concrete Research, 1990, 20(5), p. 778-782.

11. APPA RAO, G. Development of strength with age of mortars containing silica fume. Cement and Concrete Research, 2001, 31(81), p. 1141-1146.

12. BENZET, J. C.; BENHASSINE, A. Influence de la taille des particules sur la réactivité pouzzolanique des poudres de quartz. In Bulletin des Laboratoires des Ponts et Chaussées, No 219, 1999, p. 17-28 (in French).

13. LAWRENCE, P.; CYR, M. and RINGOT, E. Mineral admixtures in mortars. Cement and Concrete Research, 2003, 33(12), p. 1939-1947.

14. CYR, M.; LAWRENCE, P.; RINGOT, E. and CARLESGIBERGUES, A. Variability of efficiency factors characterising mineral admixtures. Materials and Structures, 2000, 33(7), p. 466-472.

15. LAWRENCE, P. Sur l'activité des cendres volantes et des additions minérales chimiquement inertes dans les matériaux cimentaires. Thèse de doctorat de l'université Paul Sabatier, Toulouse, France, 2000 (in French).

16. KARA ALI, R.; GALliAS, J. L. Actions des additions minérales sur la maniabilité et les caractéristiques mécaniques des mortiers. Premières rencontres internationales de Toulouse sur la science des matériaux et les propriétés des bétons, Toulouse, 5-6 Mars 1998, p. 72-77 (in French).

17. NF EN 196.1 Standard. Methods of testing cement - determination of strength. French Association of Standardization, Paris, Cedex, 1990, p. 6-19.

18. NF P18 305 Standard. Ready-mixed concretes. National Trade Union of the Ready-Mixed Concrete, Paris, 1996, p. $18-21$.

19. BOUDCHICHA, A.; GALLIAS, J. L. and MEZGHICHE, B. Utilisation d'une nouvelle approche méthodologique pour l'évaluation de l'effet des additions minérales sur les propriétés des mélanges cimentaires. In Colloque méditerranéen sur les matériaux, Oran, Algeria, 6-7 Déc 2005 (CD-ROM) (in French).

20. BOUDCHICHA, A.; CHEIKH ZOUAOUI, M.; GALLIAS, J. L. and MEZGHICHE, B. Contribution of the chemical reactivity of admixtures to the improvement of the cementing materials properties. In Proc of $11^{\text {th }}$ Asian Pacific Confederation of Chemical Engineering Congress APCCHE 2006, Kuala Lumpur, Malaysia, 2730 Aug, 2006 (CD-ROM).

21. BARON, J.; OLIVIER, J. P. Les bétons, bases et données pour leur formulation. Eyrolles, 1997 (in French).

22. HOUSSON, S.; GULHOT, B. and PERA, J. Influence of different fillers on the hydration of $\mathrm{C}_{3} \mathrm{~S}$. In Proc of $9^{\text {th }}$ ICCC, New Delhi, India, 1992, p. 430-435.

23. Xi, Y.; SIEMER, D. D. and SCHEETZ, B. E. Strength development, hydration reaction and pore structure of autoclaved slag cement with added silica fume. Cement and Concrete Research, 1997, 27(1), p. 75-82. 


\section{MINERALINIŲ PRIEDU ITAKOS SKIEDINIŲ STIPRIUI ANALIZ : FERET MODELIO TAIKYMAS}

\section{A. Boudchicha, M. Cheikh Zouaoui, J. L. Gallias, B. Mezghiche}

\section{Santrauka}

Smulkiu ir labai smulkių mineraliniu priedų naudojimas cementiniuose skiediniuose sukelia fizikinius, cheminius bei mikrostruktūrinius efektus. Šiems efektams įvertinti siūloma metodika, pagal kurią cemento kiekis skiedinio mišinyje pakeičiamas mineralinių priedų kiekiu taip, kad mišinio slankumas lieka nepakitęs. Skiedinių su priedais stipris gniuždant, atsižvelgiant i i sutankinimo laipsnį, nustatytas, taikant Feret modelị. Tai leidžia išskirti priedų itaką cementinio akmens sutank jimui nepriklausomai nuo fizikinių ir cheminių procesų. Kiekvieno priedo cheminis poveikis buvo ịvertintas analizuojant aktyvumo koeficiento $\mathrm{K}$ kitimą pagal pakeičiamo cemento kiekị. Analiz taip pat atlikta taikant ekvivalentinio rišiklio koncepciją bei aktyvumo koeficientą, nustatytą taikant Feret modelị.

Reikšminiai žodžiai: skiedinys, mineraliniai priedai, vandens poreikis, tankumas, stipris, fizinis ir cheminis efektas, Feret modelis.

Abdelaziz BOUDCHICHA. Assistant Professor at the Dept of Civil Engineering, University Larbi Ben Mehidi, Oum Bouaki Algeria, since 1993. Member of the Laboratory for Mechanics and Materials in Civil Engineering, University of Cergy Pontoise, France. Main research interests: new materials, formulation of concrete, short-term properties of cementing materials, reinforced and prestressed concrete.

Mustapha CHEIKH ZOUAOUI. Assistant Professor at the Dept of Civil Engineering, University Larbi Ben Mehidi, Oum Bouaki Algeria, since 1993. Member of the Laboratory of Materials and Durability of Structures, University of Constantine, Algeria and the Laboratory of Materials and Constructions Sciences, University of Cergy Pontoise, France. Main research interests: new materials, short-term properties of cementing materials, durability of structures, reinforced and prestressed concrete.

Jean-Louis GALLIAS. Professor at the IUP of Civil Engineering, University of Cergy Pontoise, France. Director of researches at the the Laboratory for Mechanics and Materials in Civil Engineering. Main research interests: new materials, methods of formulation of concrete, special concretes (HPC, UHPC etc).

Bouzidi MEZGHICHE. Professor at the Dept of Civil Engineering, University Mohamed Khider, Biskra, Algeria since 1989. Director of researches at the Laboratory of Concrete, University of Biskra. Main research interests: local materials, formulation of concretes. 